\title{
THE NATURE OF THE MECHANISM OF THE SHOCK PRODUCED BY THE INJECTION OF TRYPSIN AND THROMBIN
}

\author{
By H. J. TAGNON \\ (From the Thorndike Memorial Laboratory, Second and Fourth Medical Services (Harvard), Boston \\ City Hospital, and the Department of Medicine, Harvard Medical School, Boston)
}

(Received for publication June 16, 1943)

\section{INTRODUCTION}

Certain authors have postulated ( 1 to 4$)$ that the intravenous administration of crystalline trypsin into animals causes a type of shock that is similar to that produced in anaphylaxis or after peptone injection.

The following argument is developed by these authors in order to support this hypothesis. Histamine is released when smooth muscle is perfused with trypsin solution (2); and a similar production of histamine occurs in anaphylactic shock $(5,6)$. In trypsin shock, a prolonged clotting time of the blood is observed, which these authors attribute to the presence of heparin (7). In peptone (8) and in anaphylactic shock, delayed coagulation also occurs due to heparin, which has actually been isolated (9) from the blood of dogs in anaphylactic shock.

Since trypsin possesses the power to coagulate blood by converting prothrombin to thrombin even in the absence of ionic calcium (10), it seemed interesting to determine whether this production of thrombin is a factor in the shockproducing activity of trypsin. Accordingly, the effects of the injection of trypsin and thrombin on the blood pressure and the blood coagulation mechanism were compared in experimental animals.

\section{MATERIAL AND METHOD}

Sixty-eight rabbits and 17 mongrel dogs were used as experimental animals. Blood pressure was recorded by a mercury manometer after cannulation of the carotid artery, in rabbits, or the femoral artery, in dogs. Four-tenths $\mathrm{ml}$. per $\mathrm{kgm}$. of body weight of a 10 per cent solution of nembutal, injected intravenously, was used for anesthesia. The anesthesia was occasionally supplemented with ether during the preparation and cannulation of the artery in rabbits but the administration of ether was discontinued after completion of the operative procedure. Injections were made into the ear vein of the rabbits or into one of the leg veins in dogs. Occasionally, the femoral artery of the dog was used for injection. Unless otherwise specified, all injections were completed within 5 to 15 seconds. Blood samples were taken by syringe and needle from the carotid artery of rabbits or from the jugular vein of dogs. Plasma was obtained from citrated blood by spinning at 2,000 r.p.m. for 15 minutes. One ml. of 2.5 per cent sodium citrate for $9 \mathrm{ml}$. of blood was used as anticoagulant.

Trypsin. A crystalline trypsin preparation containing 85 per cent magnesium sulfate was dissolved in $10 \mathrm{ml}$. of physiological saline for injection into rabbits, in $20 \mathrm{ml}$. of physiological saline for injection into dogs. ${ }^{1}$

Heparin. Lederle heparin solution, containing $10 \mathrm{mgm}$. per ml., was employed. Each mgm. assays 110 Toronto units.

Thrombin. A pseudo-globulin fraction 2 prepared from the plasma of rabbits was used as a source of thrombin. The properties of this preparation have been described by several authors $(11,12)$. A 12.5 per cent aqueous solution of this readily soluble dry powder was employed.

Fibrinogen. A 0.4 per cent solution in distilled water of a dried preparation, made by alcohol precipitation, ${ }^{2}$ was used.

Coagulation time of whole blood. This was measured at $37^{\circ} \mathrm{C}$. by the method described by Patek and Stetson (13).

Coagulation time of recalcified citrated plasma. Citrated plasma was recalcified, using $0.1 \mathrm{ml}$. of 1.25 per cent $\mathrm{CaCl}_{2}$ for each $0.5 \mathrm{ml}$. of plasma. The clotting time was measured at $37^{\circ} \mathrm{C}$. The clotting time of recalcified plasma has been used in the past as a measure of prothrombin (14).

Prothrombin. This was estimated at $37^{\circ} \mathrm{C}$. by measuring the "prothrombin time," according to Quick. When the quantity of fibrinogen in plasma was found to be abnormally low as a result of the experimental procedure, the prothrombin time was also measured after addition of $0.1 \mathrm{ml}$. of a 0.4 per cent solution of fibrinogen to $0.1 \mathrm{ml}$. of plasma.

Protamine titration of heparin. The discovery (15) that salmine sulfate (protamine) combines quantitatively with heparin, both in vivo and in vitro, thereby neutralizing its anticoagulant effect, provided a procedure for determining whether heparin was present or not. A 2.2 per cent

\footnotetext{
1 Obtained from the Plaut Research Laboratories, Bloomfield, New Jersey.

2 Obtained through the courtesy of the Lederle Laboratories, Inc., Pearl River, New York.

- Obtained by the courtesy of Dr. E. J. Cohn, from the Department of Physical Chemistry, Harvard Medical School.
} 
aqueous solution of protamine 4 was used for the titration of heparin which was carried out as follows: to samples of $0.5 \mathrm{ml}$. of citrated plasma in $100 \mathrm{~mm}$. by $13 \mathrm{~mm}$. test tubes, decreasing quantities of protamine were added and then the plasma was recalcified by the addition of $0.1 \mathrm{ml}$. of 1.25 per cent $\mathrm{CaCl}_{2}$ and the clotting time noted at $37^{\circ} \mathrm{C}$. Since protamine itself has a slight anticoagulant action, the amount of protamine required to neutralize heparin is that amount which gives the shortest clotting time of the plasma sample.

Fibrinogen estimation in the plasma. This was done by a modification of that method (16) which is based on the estimation of fibrin produced in plasma, diluted 30 times with saline, by the addition of calcium. In plasma containing heparin, this method gives uncertain results since fibrin formation on recalcification is considerably delayed by heparin. Thromboplastin, however, added in suitable quantities, overcomes the inhibitory action of such quantities of heparin as were used in this work. Accordingly, in samples of plasma containing heparin, the method was modified by the addition to the clotting mixture of $0.5 \mathrm{ml}$. of thromboplastin prepared according to Quick (17). As shown elsewhere (18), this modification permits an accurate estimation of fibrinogen in plasma containing quantities of heparin in excess of those used in this work.

A qualitative test for fibrinogen, sometimes used in this work, is based on the fact that if the quantity of fibrinogen in plasma is very small, no clot is produced on addition of $\mathrm{CaCl}_{2}$ to the 30 times diluted plasma. In the absence of an anticoagulant, the failure of production of a clot, under these circumstances, is by itself sufficient indication that the level of fibrinogen is markedly decreased. In those experiments in which this test was used, the notation "decreased" without qualification is substituted for the quantitative determination in $\mathrm{mgm}$. of fibrinogen.

\section{RESULTS}

\section{The effect of intravenous injection of trypsin}

A. Lethal dose and autopsy findings. As shown in Figure 1, the mortality rate in rabbits increased steadily with increasing doses of trypsin, when injected within 10 to 15 seconds. Quantities of trypsin larger than $8 \mathrm{mgm}$. were lethal for all injected rabbits. However, when doses of $10 \mathrm{mgm}$. and $11 \mathrm{mgm}$. per $\mathrm{kgm}$. were dissolved in $20 \mathrm{ml}$. of saline and administered at a slow rate ( 25 minutes and 52 minutes respectively), they did not produce death (rabbits, No. 14 and No. 16).

Gross intravascular coagulation was found at post mortem examination in most rabbits dying after the injection of amounts greater than 8 mgm. of trypsin. However, no such gross

\footnotetext{
4 Kindly supplied by Lilly Research Laboratories.
}

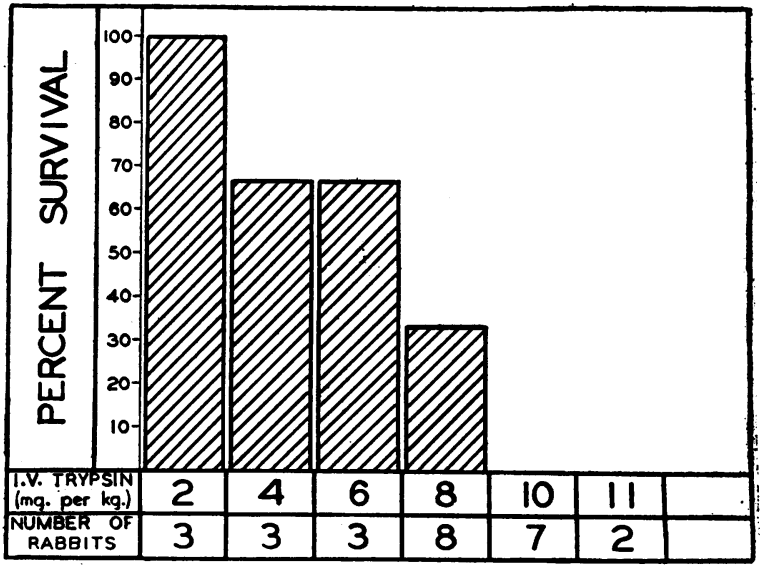

Fig. 1. Effect of Intravenous Injection of Trypsin on Mortality Rate of Rabitts

intravascular coagulation was found in 3 rabbits killed by the injection of $8 \mathrm{mgm}$. All animals injected with 10 and $11 \mathrm{mgm}$. showed gross intravascular coagulation at post mortem examination.

TABLE I

The effect of intravenous injection of trypsin on blood pressure Animals under nembutal

\begin{tabular}{|c|c|c|c|}
\hline & \multirow[b]{2}{*}{ Trypsin } & \multicolumn{2}{|c|}{ Blood pressure } \\
\hline & & Initial & $\begin{array}{c}\text { Within } 2 \mathrm{~min} . \\
\text { after } \\
\text { injection }\end{array}$ \\
\hline & mgm. per kgm. & \multicolumn{2}{|c|}{$m m . H_{g}$} \\
\hline $\begin{array}{r}\text { Rabbits, nos. } 27 \\
28 \\
75 \\
62 \\
63 \\
64 \\
65 \\
66 \\
67 \\
70 \\
71 \\
72\end{array}$ & $\begin{array}{l}2 \\
2 \\
2 \\
4 \\
4 \\
4 \\
6 \\
6 \\
6 \\
8 \\
8 \\
8\end{array}$ & $\begin{array}{r}105 \\
110 \\
120 \\
110 \\
90 \\
100 \\
110 \\
90 \\
120 \\
110 \\
120 \\
110\end{array}$ & $\begin{array}{r}95 \\
105 \\
115 \\
50 \\
60 \\
55 \\
60 \\
50 \\
90 \\
40 \\
50 \\
45\end{array}$ \\
\hline Dogs, nos. $\begin{array}{r}3 \\
12 \\
4 \\
8 \\
22\end{array}$ & $\begin{array}{l}2 \\
2 \\
2 \\
2 \\
2\end{array}$ & $\begin{array}{l}170 \\
155 \\
160 \\
150 \\
155\end{array}$ & $\begin{array}{l}90 \\
80 \\
75 \\
60 \\
60\end{array}$ \\
\hline
\end{tabular}

B. Effect on blood pressure. In rabbits (Table I), doses of $4 \mathrm{mgm}$. per $\mathrm{kgm}$. of trypsin solution, and above, produced marked and immediate fall in blood pressure, which returned to normal in from 6 to 16 minutes in surviving animals. 


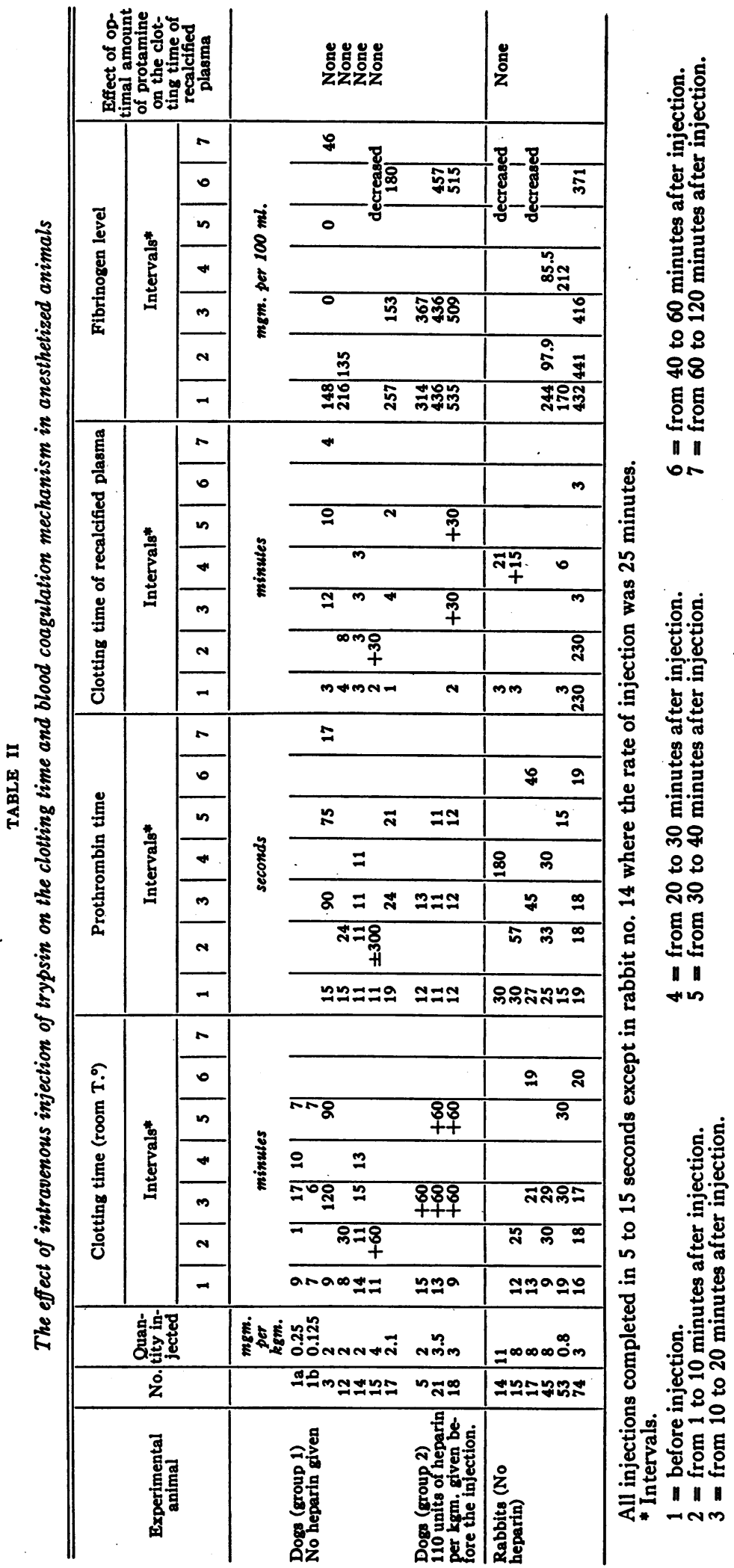


In dogs (Table I), 2 mgm. of trypsin solution per $\mathrm{kgm}$. produced a marked fall in blood pressure with a similar return to normal after 6 to 16 minutes. A typical recording of the blood pressure during and after administration of trypsin is shown in Figure 2.

C. Effect on the coagulation mechanism of the blood. Prolongation of the clotting time was observed in 4 of 7 dogs following the intravenous injection of varying quantities of trypsin (Table II, group 1). Dog 1a showed a shortening of the clotting time preceding the prolongation. In rabbits, a prolongation of the clotting time, following the injection of varying amounts of trypsin, was observed in 5 of 6 injected animals (Table II, rabbits Nos. 14, 15, 17, 45, 53).

Coincident with the prolongation of the clotting time in dogs and rabbits, there appeared a prolonged prothrombin time which persisted after addition of $0.1 \mathrm{ml}$. of 0.4 per cent solution of fibrinogen to the plasma sample. The recalcification time was prolonged, but, except in dog No. 15 and rabbit No. 15, less markedly than the clotting time of whole blood. The fibrinogen level in blood samples showing a prolonged clotting time was found significantly decreased (Table II, dogs Nos. 3, 15, 12; rabbits Nos. 14, 15, 7).

In an attempt to detect the presence of heparin in blood showing a prolonged clotting time, a protamine titration was carried out, in a certain number of instances, on samples of citrated plasmas obtained from such blood. The results are shown in Table II. In no instance was the prolonged clotting time of recalcified plasma

TABLE III

\section{Absence of anticoagulant action of plasma obtained after} shock produced by intravenous injection of trypsin

Five-tenths ml. of citrated plasma obtained from blood showing a prolonged clotting time as a result of intravenous injection of trypsin (dogs No. 12, No. 3, No. 15, Table II) was added to $0.5 \mathrm{ml}$. of normal plasma. The mixture was recalcified and the clotting time compared with the clotting time of normal recalcified plasma.

\begin{tabular}{ccc}
\hline \hline & \multicolumn{2}{c}{ Clotting time at $37^{\circ}$ C. (seconds) } \\
\cline { 2 - 3 } Dog No. & Normal plasma & $\begin{array}{c}\text { Normal plasma } \\
\text { + trypoin shock plasma }\end{array}$ \\
\hline 12 & 240 & 285 \\
3 & 180 & 170 \\
15 & 195 & 180 \\
\hline
\end{tabular}

TABLE IV

The effect of heparin upon the toxicity of trypsin injected intravenously into unanesthetized rabbits

\begin{tabular}{|c|c|c|c|}
\hline Rabbits & No. & $\begin{array}{l}\text { Trypsin } \\
\text { mgm. } \\
\text { per } \mathbf{k g m} \text {. }\end{array}$ & Results \\
\hline $\begin{array}{l}\text { Group 1: } 110 \text { units of } \\
\text { heparin per kgm. } \\
\text { given before the } \\
\text { injection. }\end{array}$ & $\begin{array}{l}7 \\
8 \\
11 \\
12 \\
83(\mathrm{a}) \\
76 \\
77 \\
79 \\
80\end{array}$ & $\begin{array}{r}10 \\
10 \\
12 \\
12 \\
5 \\
5 \\
5 \\
5 \\
5\end{array}$ & $\begin{array}{l}\text { No symptoms } \\
\text { No symptoms } \\
\text { No symptoms } \\
\text { No symptoms } \\
\text { No symptoms } \\
\text { No symptoms } \\
\text { No symptoms } \\
\text { No symptoms } \\
\text { No symptoms }\end{array}$ \\
\hline $\begin{array}{l}\text { Group 2: No heparin } \\
\text { given. }\end{array}$ & $\begin{array}{l}81 \\
82 \\
83(b) \\
84 \\
85\end{array}$ & $\begin{array}{l}5 \\
5 \\
5 \\
5 \\
5\end{array}$ & $\begin{array}{l}\text { Agitation, sneezing, } \\
\text { recovery } \\
\text { Death, } 15 \text { minutes } \\
\text { Death, } 15 \text { minutes } \\
\text { Agitation, sneezing, } \\
\text { recovery } \\
\text { Agitation, sneezing, } \\
\text { recovery }\end{array}$ \\
\hline
\end{tabular}

brought to normal by the addition of an optimal amount of protamine.

To detect the presence of an anticoagulant other than heparin in blood showing a prolonged clotting time, which could not be demonstrated by the use of protamine, citrated plasma obtained from such blood was added to normal plasma, and the clotting time of the mixture on recalcification noted. The clotting time of normal plasma was not found to be prolonged after such addition (Table III).

\section{Effect of preliminary administration of heparin upon the syndrome of trypsin shock}

A. Effect on toxicity of trypsin. Lethal doses of trypsin did not produce death in rabbits previously injected with 110 units of heparin per $\mathrm{kgm}$. of body weight (Table IV, Nos. 7, 8, 11, 12). Also, there were no deaths and no toxic symptoms in a series of 5 unanesthetized rabbits (Table IV, Nos. 83a, 76, 77, 79, 80) given heparin before the injection of $5 \mathrm{mgm}$. of trypsin per $\mathrm{kgm}$. of body weight. This dose produced death in 2 of 5 non-heparinized animals (Table IV, Nos. 87, 82, 83b, 84, 85).

B. Effect on blood pressure. The fall in blood pressure produced by trypsin was not affected by preliminary heparinization (Figure 2). This observation was repeated in a second animal (No. 2) and in this case also, the fall in blood 

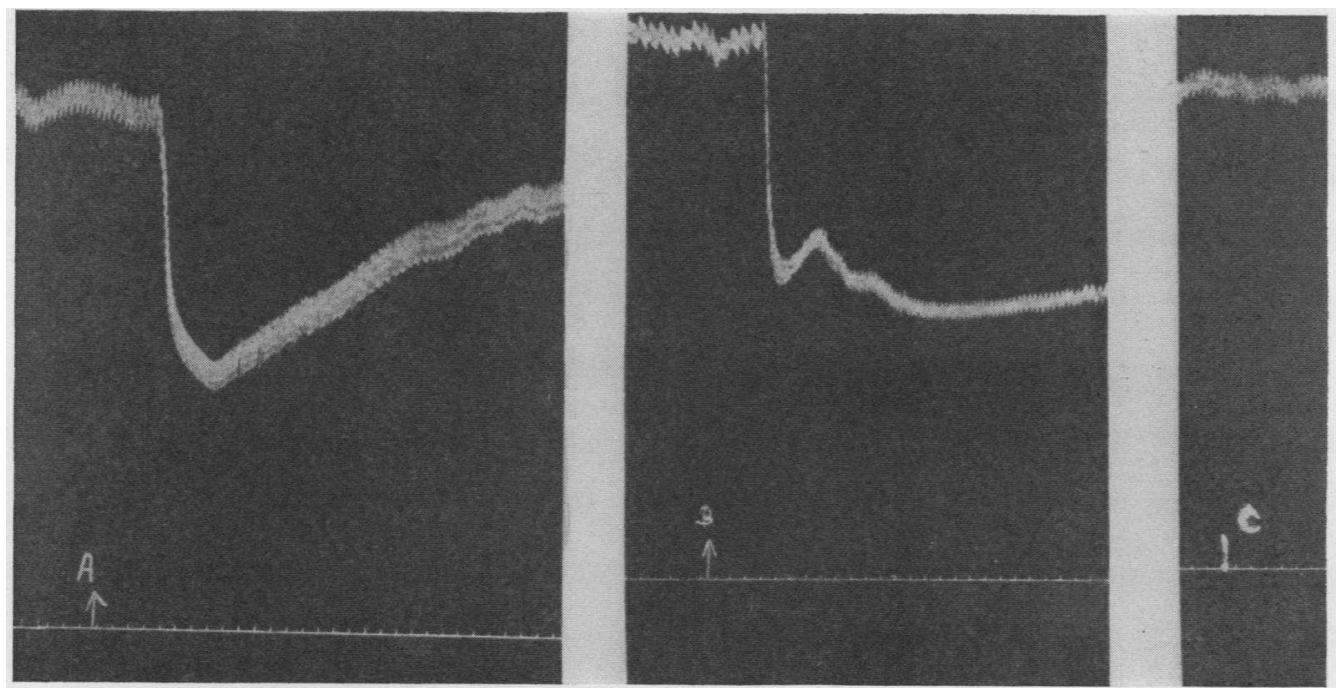

Fig. 2. Effect on Blood Pressure of Intravenous Injection of 2 mgm. OF TRYPSIN PER KGM. INTO DOGS

Time intervals 6 seconds.

A. Injection of trypsin preceded by administration of 110 units of heparin per kgm. (dog No. 21)

B. No heparin given (dog No. 17)

C. Same as B, 16 minutes later

pressure was unaffected by preliminary administration of heparin.

C. Effect on the blood coagulation mechanism. When heparin was given prior to the injection of trypsin, although the clotting time was found to be prolonged as the result of the injection of heparin, no significant changes were observed in the prothrombin time and the fibrinogen level (Table II, dogs: group 2).

\section{Effect of anaphylactic and peptone shock on blood coagulation mechanism}

For purposes of comparison, the blood coagulation mechanism following anaphylactic shock in 3 rabbits (Table V, Nos. 18, 20, 22) and $1 \mathrm{dog}$ (Table V, No. 25) and peptone shock in $1 \mathrm{dog}$ (Table V, No. 26) were studied. The rabbits were sensitized to human plasma by 4 intraperitoneal injections of $5 \mathrm{ml}$. of human plasma

TABLE V

Blood clotting time and coagulation mechanism during anaphylactic and peptone shock

\begin{tabular}{|c|c|c|c|c|c|c|c|c|}
\hline \multirow[t]{2}{*}{$\begin{array}{l}\text { Experimental } \\
\text { animal }\end{array}$} & \multirow[t]{2}{*}{ No. } & \multicolumn{2}{|c|}{$\begin{array}{l}\text { Clotting time } \\
\left.\text { (room } \mathrm{T} .{ }^{\circ}\right)\end{array}$} & \multicolumn{2}{|c|}{$\begin{array}{l}\text { Prothrombin time } \\
\left(37^{\circ} \mathrm{C} .\right)\end{array}$} & \multicolumn{2}{|c|}{$\begin{array}{l}\text { Clotting time of recalcified } \\
\left(37^{\circ} \mathrm{C} .\right) \text { plasma }\end{array}$} & \multirow{2}{*}{$\begin{array}{l}\text { Effect of addition of } \\
\text { optimal amount of pro- } \\
\text { tamine on clotting time } \\
\text { of recalcified plasma }\end{array}$} \\
\hline & & A & B & $\mathbf{A}$ & B & A & B & \\
\hline$\cdot$ & & \multicolumn{2}{|c|}{ minutes } & \multicolumn{2}{|c|}{ seconds } & \multicolumn{2}{|c|}{ minutes } & \\
\hline $\begin{array}{l}\text { Rabbit* } \\
\text { Rabbit* } \\
\text { Rabbit* } \\
\text { Dog* } \\
\text { Dogt }\end{array}$ & $\begin{array}{l}18 \\
20 \\
22 \\
25 \\
26\end{array}$ & $\begin{array}{r}12 \\
9 \\
10 \\
10 \\
8\end{array}$ & $\begin{array}{r}22 \\
18 \\
22 \\
+60 \\
+60\end{array}$ & $\begin{array}{l}25 \\
26 \\
23 \\
12 \\
13\end{array}$ & $\begin{array}{l}26 \\
26 \\
23 \\
12 \\
13\end{array}$ & $\begin{array}{l}2 \\
2 \\
2 \\
4 \\
2\end{array}$ & $\begin{array}{r}20 \\
15 \\
16 \\
+60 \\
+60\end{array}$ & $\begin{array}{l}\text { Brought to normal } \\
\text { Brought to normal } \\
\text { Not done } \\
\text { Brought to normal } \\
\text { Brought to normal }\end{array}$ \\
\hline
\end{tabular}

$\mathrm{A}=$ before anaphylaxis or injection of peptone.

$\mathrm{B}=$ within 10 minutes after production of shock.

* Anaphylactic shock. $\dagger$ Peptone shock. 
TABLE VI

Anticoagulant action of anaphylactic and peptone shock

Five-tenths ml. of citrated plasma obtained from blood showing a prolonged clotting time as a result of anaphylaxis (dog No. 25) or intravenous injection of peptone (dog No. 26) (see Table VII) was added to $0.5 \mathrm{ml}$. of normal plasma. The mixture was recalcified and the clotting time compared to the clotting time of normal recalcified plasma.

\begin{tabular}{lcc}
\hline \hline & \multicolumn{2}{c}{ Clotting time at $37^{\circ}$ C. (minutes) } \\
\cline { 2 - 3 } & $\begin{array}{c}\text { Normal } \\
\text { plasma }\end{array}$ & $\begin{array}{c}\text { Normal plasma } \\
\text { + shock plasma }\end{array}$ \\
\hline Dog No. 25 & 4 & +55 \\
Dog No. 26 & 2 & +30 \\
\hline
\end{tabular}

given at 2-day intervals. Anaphylactic shock was produced by giving $5 \mathrm{ml}$. of human plasma intravenously, 2 weeks after the last injection. Dog No. 25 received $10 \mathrm{ml}$. of human plasma intravenously and shock was produced by the intravenous injection of $10 \mathrm{ml}$. of the same material 2 weeks later. Dog No. 26 received a single intravenous injection of $33 \mathrm{ml}$. of a 10 per cent peptone solution.

Anaphylactic and peptone shock were accompanied by a prolongation of the clotting time of whole blood and of recalcified plasma. No changes in the prothrombin time were observed. A protamine titration was carried out on plasma samples showing a prolonged clotting time on recalcification in rabbits Nos. 18 and 20, and dogs Nos. 19 and 20. The data demonstrated the presence of heparin in the blood of all of the shocked animals. The results of a typical protamine titration are given in Table VII.

\section{TABLE VII}

\section{Protamine titration of plasma during anaphylactic shock}

Five-tenths ml. of citrated plasma obtained from blood showing a prolonged clotting time as a result of anaphylaxis (see Table VI, dog No. 25) was added to varying quantities of protamine. The plasma was recalcified and the clotting time noted.

\begin{tabular}{cc}
\hline \hline Protamine & Clotting time $\left(37^{\circ} \mathrm{C}.\right)$ \\
\hline mgm. & minutes \\
0.5 & 25 \\
0.1 & 10 \\
0.05 & 3 \\
0.02 & 3 \\
0.005 & 10 \\
0 & +60 \\
\hline
\end{tabular}

\section{Effect of intravenous injection of thrombin}

A. Lethal dose and autopsy findings in anesthetized animals. One one-hundredth $\mathrm{ml}$. of the
12.5 per cent solution of thrombin per $\mathrm{kgm}$. of body weight did not cause death in 3 rabbits (Nos. 23, 24, 27). Of 11 rabbits receiving 0.1 ml., 4 died within 30 minutes (Nos. 25, 31, 38, 39). All 5 rabbits injected with $0.2 \mathrm{ml}$. per kgm. died (Nos. 95, 96, 97, 50, 48).

Post mortem examination failed to reveal gross intravascular coagulation in all animals dying from the injection. For instance, 2 of the 4 rabbits killed by the injection of $0.1 \mathrm{ml}$. of thrombin per $\mathrm{kgm}$. of body weight had no gross intravascular coagulation. However, all rabbits injected with $0.2 \mathrm{ml}$. per $\mathrm{kgm}$. of body weight showed gross intravascular coagulation at post mortem examination.

Of 4 dogs injected with $0.03 \mathrm{ml}$. of thrombin per kgm. of body weight, 1 died and showed no gross intravascular coagulation at post mortem examination.

B. Effect on blood pressure. A marked and immediate fall in blood pressure followed the injection of $0.1 \mathrm{ml}$. of thrombin or more per $\mathrm{kgm}$. of body weight into rabbits (Table VIII, group 1), and of $0.03 \mathrm{ml}$. in the only dog upon which the blood pressure was recorded (Table VIII, No. 6). A typical recording of the blood pressure during and after intravenous injection of thrombin, is given in Figure 3.

C. Effect on the coagulation mechanism. A prolongation of the clotting time was observed after injection into rabbits of $0.1 \mathrm{ml}$. or more of thrombin per $\mathrm{kgm}$. of body weight (Table VIII, Nos. 25, 31, 41, 32). This prolongation of the clotting time was accompanied by a prolonged prothrombin time and a somewhat prolonged clotting time of recalcified plasma. The fibrinogen level was found decreased after the injection of thrombin in 2 rabbits upon which the determination was carried out (Table VIII, Nos. 43, 32). No changes in prothrombin and fibrinogen were caused in rabbits by the injection of $0.01 \mathrm{ml}$. per kgm. of body weight (Nos. 47, 23, 24).

In dogs, the results of the intravenous injections of thrombin were essentially the same as in rabbits, but were produced by smaller doses of thrombin (Table VIII).

A protamine titration was carried out on plasma samples which showed a delayed clotting time on recalcification (rabbit No. 31). This prolonged coagulation time could not be brought 


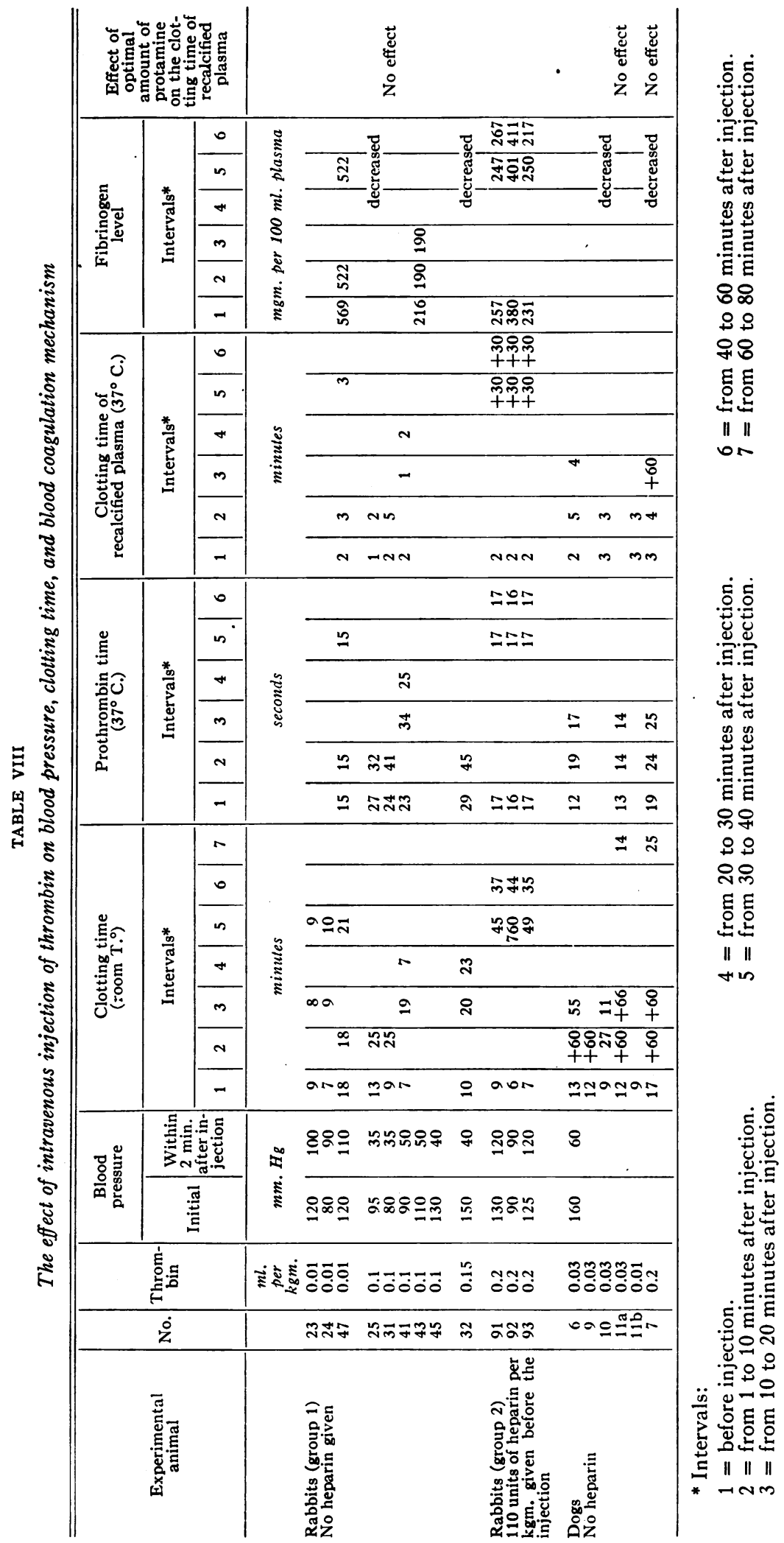




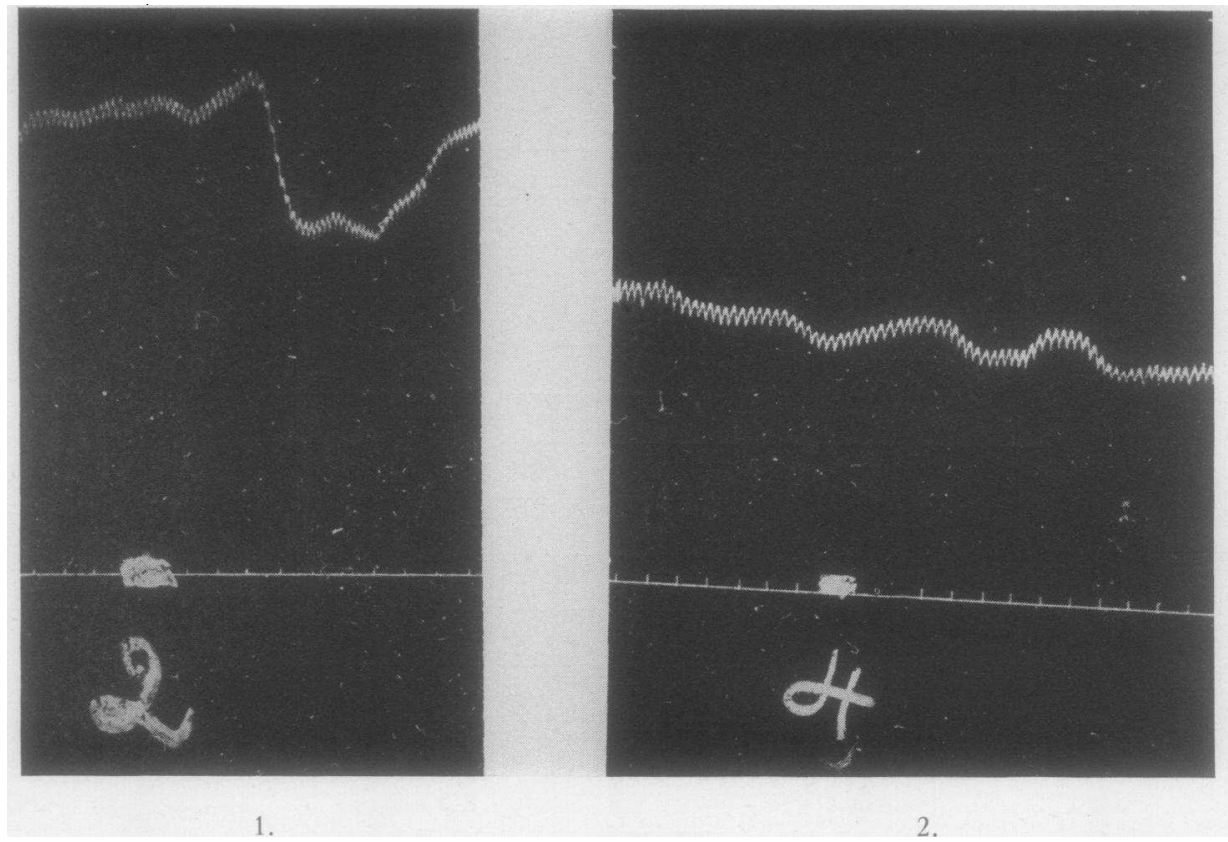

Fig. 3. Effect on Blood Pressure of Intravenous Injection OF THROMBIN INTO RABBITS

Time intervals 6 seconds.

1. Injection of $0.1 \mathrm{ml}$. per $\mathrm{kgm}$. (rabbit No. 31)

2. Injection of $0.2 \mathrm{ml}$. per $\mathrm{kgm}$. preceded by administration of 110 units of heparin per $\mathrm{kgm}$. (rabbit No. 93)

to normal by the addition of suitable quantities of protamine (Table VIII) and consequently was not due to the presence of heparin.

\section{Effect of preliminary administration of heparin upon the syndrome of thrombin shock}

A. Effect of toxicity. A dose of $0.2 \mathrm{ml}$. of thrombin per $\mathrm{kgm}$. of body weight, which proved lethal in all other injected rabbits, did not kill any of the 3 heparinized rabbits (Table VIII, group 2).

B. Effect on the blood pressure. A typical tracing is given in Figure 3 (Rabbit No. 91). It was found that the intravenous injection of $0.2 \mathrm{ml}$. of thrombin in rabbits (Nos. 92 and 93) which had been previously heparinized had no effect on the blood pressure (Table VIII).

C. Effect on blood coagulation mechanism. After such an injection of thrombin in 3 heparinized rabbits, the clotting time of whole blood and the clotting time of recalcified plasma were prolonged as a result of the injection of heparin, but the prothrombin time and the fibrinogen levels were not significantly altered (Table VIII, group 2).

\section{DISCUSSION}

The similarity of the states of shock produced by trypsin and by anaphylaxis has been emphasized (1 to 4). It was shown that in both conditions, histamine was released from smooth muscle and that histamine could account for some of the symptoms following the injection of trypsin. To heparin is attributed the prolongation of the clotting time observed during trypsin shock.

The data presented here permit a comparison between certain features of anaphylactic shock and trypsin shock. A fall in blood pressure and a prolongation of the clotting time are observed in both conditions. In anaphylactic shock, the prolongation of the clotting time is clearly due to release of heparin (6). As a result, the clotting time of recalcified plasma is markedly prolonged (Table V). Moreover, suitable quan- 
tities of protamine, which neutralize heparin, bring back to normal the prolonged clotting time of recalcified plasma. Finally, the presence of an anticoagulant in plasma obtained during anaphylaxis is readily demonstrated by the prolongation of clotting time of normal plasma by such plasma. The prothrombin time has been shown not to be affected by quantities of heparin such as are found in anaphylactic (18) or peptone (17) shock and is, therefore, normal in these two conditions.

In trypsin shock, in the experiments reported here, the prolonged clotting time was associated with a prolonged prothrombin time, a slightly prolonged clotting time of recalcified plasma, and a decreased fibrinogen level in the plasma. The prolonged clotting time of recalcified plasma was, however, not shortened by the addition of suitable quantities of protamine, and the clotting time of normal plasma was not prolonged by the addition of trypsin shock plasma. It would, therefore, appear that the prolongation of the clotting time following intravenous injection of trypsin was not due to the presence of heparin or any other anticlotting agent and could be explained on the basis of the decreased prothrombin and fibrinogen.

The changes in blood coagulation observed after the intravenous injection of thrombin were identical with those following trypsin injections and were similarly associated with changes in the prothrombin and fibrinogen content of plasma. In the experiments reported here, no anticoagulant could be detected in the blood following intravenous injections of thrombin and, therefore, the prolongation of the clotting time appears to be due also to the change in prothrombin time and fibrinogen content of the plasma.

Preliminary administration of heparin prevented the decrease in fibrinogen content and lengthening of the prothrombin time caused by the injection of trypsin or of thrombin. This observation offers support to the thesis that the cause of the changes in the blood coagulation, as well as in fibrinogen and prothrombin concentrations, following the injection of both trypsin and of thrombin, lies in the coagulating activity of these substances. The simplest explanation for the decrease of fibrinogen and prothrombin following intravenous injection of trypsin or thrombin is that intravascular coagulation of the blood occurred. The absence of macroscopic clots in a number of instances is understandable if the fibrin so formed was deposited throughout the organism on the walls of the blood vessels. From 300 to $400 \mathrm{mgm}$. of fibrin from a blood volume of $200 \mathrm{ml}$. in a rabbit, deposited as a fine layer throughout the relatively enormous vascular bed, might well have escaped detection at autopsy. This theory is further supported by one experiment (dog No. 1a, Table I) in which the usual prolonged clotting time was preceded by a shortened clotting time.

The decrease in prothrombin following the intravenous injection of thrombin would seem to indicate that in vivo, the injected thrombin produces fibrin from fibrinogen in the usual fashion but in addition, since calcium ions are present, and in contrast to what happens when it is added to citrated or oxalated blood, sets in motion the production of more thrombin from prothrombin with subsequent consumption of prothrombin and fibrinogen. When trypsin is injected, thrombin is, of course, formed from the action of trypsin on prothrombin and the action of the newly formed thrombin, identical with that of injected thrombin, may account for the small amount of trypsin required in vivo to produce coagulation, as compared to the relatively large amount $(1 \mathrm{mgm}$. per $2 \mathrm{ml}$. of citrated blood) needed in vitro on citrated or oxalated blood containing no calcium ion. The possibility of such an explanation seems to have been overlooked by other investigators of the action of thrombin (19) and trypsin (7).

Trypsin differs from thrombin in that its vasodepressive action is not abolished by preliminary heparinization while that of thrombin is. This indicates that the vaso-depressive action of thrombin may be due entirely to its clotting activity. In the case of trypsin, however, the protective action of heparin against death, shown in Table IV, would seem to indicate that a part of the action of trypsin is due also to its clotting activity.

The paradoxical prolongation of the clotting time obtained in vivo by the injection of clotting agents must be considered in the search for injectable hemostatic agents to be used either in normal individuals or patients with bleeding 
tendencies, particularly hemophiliacs. It would seem that unless new methods of administration are devised, such injections may not produce the desired results.

\section{SUMMARY}

1. The prolongation of blood coagulation observed after intravenous injection of trypsin or thrombin into rabbits or dogs was found to be due to diminution of the fibrinogen and the prothrombin of the plasma.

2. Neither heparin nor any other anticoagulant was found in the circulating blood of animals during the shock phase, produced by either trypsin or thrombin.

3. The action of thrombin on the blood pressure is entirely abolished by preliminary heparinization and is, therefore, due entirely to its clotting power. The action of trypsin on the blood pressure is not abolished by preliminary heparinization.

\section{BIBLIOGRAPHY}

1. Rocha e Silva, M., The histamine theory of anaphylactic shock. Arch. Path., 1942, 33, 387.

2. Rocha e Silva, M., Beiträge zur Pharmakologie des Trypsins. Wirkung des Trypsins auf die glatten Muskeln des Dünndarms und die Gebärmutter von Säugetieren. Die Freisetzung von Histamin nach Durchströmung der Meerschweinchenlunge mit Trypsin. Arch. f. exper. Path. u. Pharmakol., 1940, 194, 335.

3. Rocha e Silva, M., Libération de l'histamine par la perfusion du poumon du cobaye au moyen de la trypsine. Compt. rend. Soc. de biol., 1939, 130, 186.

4. Dragstedt, C. A., and Rocha e Silva, M., Effect of trypsin upon blood histamine of rabbits. Proc. Soc. Exper. Biol. and Med., 1941, 47, 420.

5. Rose, B., and Weil, P., Blood histamine in the rabbit during anaphylactic shock. Proc. Soc. Exper. Biol. and Med., 1939, 42, 494.
6. Dragstedt, C. A., Anaphylaxis. Physiol. Rev., 1941, 21, 563.

7. Rocha e Silva, M., and Dragstedt, C. A., Liberation of heparin by trypsin. Proc. Soc. Exper. Biol. and Med., 1941, 48, 152.

8. Quick, A. J., On coagulation defect in peptone shock: consideration of antithrombins. Am. J. Physiol., 1936, 116, 535.

9. Jaques, L. B., and Waters, E. T., The identity and origin of the anticoagulant of anaphylactic shock in the dog. J. Physiol., 1941, 99, 454.

10. Eagle, H., and Harris, T. N., Studies in blood coagulation. V. The coagulation of blood by proteolytic enzymes (trypsin, papain). J. Gen. Physiol., 1937, 20, 543.

11. Parfentjev, I. A., A globulin-fraction in rabbit's plasma possessing a strong clotting property. Am. J. M. Sc., 1941, 202, 578.

12. Taylor, F. H. L., Lozner, E. L., and Adams, M. A., The thrombic activity of a globulin fraction derived from rabbit plasma. Am. J. M. Sc., 1941, 202, 585.

13. Patek, A. J., Jr., and Stetson, R. P., Hemophilia. I. The abnormal coagulation of the blood and its relation to the blood platelets. J. Clin. Invest., 1936, 15, 531.

14. Howell, W. H., and Cekada, E. B., The cause of the delayed clotting of hemophilic blood. Am. J. Physiol., 1926, 78, 500.

15. Chargaff, E., and Olson, K. B., Studies on the chemistry of blood coagulation. VI. Studies on the action of heparin and other anticoagulants. The influence of protamine on the anticoagulant effect in vivo. J. Biol. Chem., 1937, 122, 153.

16. Cullen, G. E., and Van Slyke, D. D., Determination of the fibrin, globulin, and albumin nitrogen of blood plasma. J. Biol. Chem., 1920, 41, 587.

17. Quick, A. J., On various properties of thromboplastin (aqueous tissue extracts). Am. J. Physiol., 1936, 114, 282.

18. Tagnon, H. J., To be published.

19. Bird, R. M., McSwain, B., Kauer, G. L., Jr., and Glenn, F., Clotting action of rabbit-clotting globulin. Proc. Soc. Exper. Biol. and Med., 1941, 48, 730. 